\title{
PROBIOTIKAI IR BURNOS SVEIKATA
}

\author{
Evelina Daugèlienė, Jurgita Andruškienė \\ Klaipèdos valstybinès kolegijos Sveikatos mokslu fakulteto Burnos priežiūros katedra
}

Raktažodžiai: probiotikai, burnos sveikata, dantų èduonis, periodontitas, halitozè.

\begin{abstract}
Santrauka
Probiotikų nauda žmogaus organizmui žinoma jau seniai, tačiau pastaraisiais dešimtmečiais probiotikų tyrinejjimai ir naudojimas labai išpopuliarejo [1]. Pasaulio sveikatos organizacijos teigimu, probiotikai - gyvi mikroorganizmai (bakterijos, mielès ir kt.), kurie, vartojami tinkamais kiekiais, yra naudingi žmogaus sveikatai. Dèl teigiamų savybių, probiotikų dedama ị ịvairius maisto produktus. Probiotikų terminas pirmą kartą paminètas 1965 metais. Probiotikai - natūraliai virškinimo trakte ir urogenitalinės sistemos gleivinejje gyvenanti mikroflora [2]. Dabartiniai tyrimai parodè, kad pusiausvyra tarp naudingų ir patogeninių bakterijų yra būtina, siekiant išsaugoti burnos sveikatą [3]. Dažniausiai aptinkami lactobacillus ir bifidobacterium grupès probiotikai. Probiotikai gali padeti atkurti burnos mikrofloros pusiausvyrą. Tyrinejjant probiotikus pastebėta, kad tam tikros jų padermès gali būti naudingos burnos sveikatai ir prisidèti prie dažniausiai paplitusių burnos ligų - dantų èduonies, blogo burnos kvapo (halitozès) ir periodontito profilaktikos [4].
\end{abstract}

\section{İvadas}

Dèl didelio bakterijų atsparumo antibiotikams, burnos ertmès ligoms gydyti pradèta taikyti probiotikų terapija. Dantų èduonis, periodonto ligos ir halitozé - tai sutrikimai, kuriems suvaldyti naudojami probiotikai. Esminè jų taikymo burnos ertmejje sąlyga - gebejjimas laikytis ir kolonizuotis prie ịvairių burnos ertmès paviršių [5].

Tyrimai rodo didelị dantų èduonies ir periodontito paplitimą. Yra duomenų, kad išsivysčiusiose pasaulio šalyse periodontitu serga apie 15-35 proc. suaugusių gyventojų [6]. Dideliam dantų eduonies ir periodontito paplitimui mažinti, taikoma daug ivvairių programų ir projektų. Burnos ligu profilaktikai vis dažniau taikoma viena iš naujausių gydymo priemonių - probiotikų terapija. Pasaulio sveikatos organizacijos teigimu, probiotikai - tai gyvi mikroorganizmai (bakterijos, mielès ir kt.), kurie, vartojami tinkamais kiekiais, yra naudingi žmogaus sveikatai [1]. Daugelis tyrejų atskleidžia probiotikų naudą burnos sveikatai. İrodyta, kad lactobacillus ir bifidobacterium grupés probiotikai slopina grybelių ir streptokokų augimą [7]. Probiotikų naudojimas burnos ligu profilaktikai ar gydymui dar nauja priemonè, bet jau yra nemažai klinikinių studijų, patvirtinančių jų naudą kontroliuoti periodontitą, gingivitą, halitozę, kandidozę bei dantų èduonị [8-10]. Dantų èduonị ir priedančio audinių ligas sukelia burnos ertmejje esančių mikroorganizmų pusiausvyros pokyčiai. Bakterijų, paimtų iš apnašo burnoje, kurioje diagnozuotas dantų éduonis ir priedančio audinių ligos, rūšys ir santykis skiriasi ne tik tarpusavyje, bet ir nuo tụ, kurios dominuoja sveikoje burnoje. Ėduonies atveju padidejja rūgštinių ir rūgštingumą toleruojančių bakterijų rūšiu, tokių kaip streptococcus mutans, tačiau galima aptikti ir kitų panašias savybes turinčių aktinomicetų, veilonelių ar bifido bakteriju, kurios taip pat svarbios šios ligos etiologijai [11].

Darbo tikslas - išanalizuoti mokslines publikacijas, kuriose aprašomi probiotikai ir jų nauda burnos sveikatai.

\section{Tyrimo medžiaga ir metodai}

Atlikta literatūros šaltinių apžvalga ir analizè. Publikacijų paieška anglų kalba atlikta tarptautinèse medicinos duomenų bazèse Medline, PubMed, Cochrane Library, Medscape ir specializuotoje informacijos paieškos sistemoje Google Scholar. Paieškai naudotos raktažodžių kombinacijos: probiotics and dental plaque, probiotics and parodontontitis, probiotics and dental caries, probiotic and oral health. Pasikartojantys ir temos neatitinkantys straipsniai iš tolimesnès straipsnių analizès pašalinti. Išsamesnei analizei atrinkti straipsniai, kuriuose nagrinejjama ir pristatoma naujausia probiotikų nauda, siekiant išsaugoti burnos sveikatą.

Probiotikų veikimo principas burnos ertmèje. Burnos ertmeje probiotikai gali sukurti biofilmą, kuris, kaip apsauginis sluoksnis, veikia burnos audinius ir taip apsaugo burnos ertmę nuo ligų. Šis biofilmas neleidžia patogenams prisitvirtinti prie burnos ertmès audinių ir konkuruoja su èduonị sukeliančiomis bakterijomis bei periodontitą suke- 
liančių bakterijų augimu [12].

Probiotikai ir dantų ėduonis. Dantų ėduonis yra viena iš dažniausiai pasitaikančių burnos ertmès ligų, vertinama kaip mikrobu pusiausvyros sutrikimas. Tyrimai rodo, kad net ir trumpai vartojami bifidobakterijų ir laktobacilu grupès probiotikai gali sumažinti kariesogeninių bakterijų lygị seilèse $[13,3]$. Dantų èduonis yra daugiaveiksnè bakterinès kilmès liga, kuriai būdingas danties emalio rūgštinis demineralizavimas. Kad apribotų ar užkirstų kelią dantų èduonies plitimui, probiotikas turi prisitvirtinti prie dantų paviršiu ir integruotis it bakterijų bendruomenes, sudarančias dantų plèvelę. Be to, probiotikas turi konkuruoti su kariesogeninemmis bakterijomis ir užkirsti kelią jų proliferacijai. Probiotikų įtraukimo ị pieno produktus pranašumas yra jų gebejjimas neutralizuoti rūgščią terpę. Keli klinikiniai tyrimai parodè, kad reguliarus jogurto, pieno ar sūrio, kuriame yra probiotikų, vartojimas sumažino kariesogeninių streptokokų kiekị seilèse ir dantų apnaše. H. Nikawa ir kolegos pastebejjo, kad joguto, kuriame yra lactobacillus reuteri, vartojimas 2 savaites, sumažino s. mutans koncentraciją seilèse iki 80 procentų. Panašūs rezultatai gauti naudojant kramtomają gumą su probiotikais ir čiulpiamąsias pastiles su probiotikais. L. Näse su kolegomis paskelbè ilgalaikio (trukusio 7 mènesius) tyrimo duomenis. Jame dalyvavo 594 vaikai nuo 1 iki 6 metų. Buvo vertinamas pieno, papildyto 1. rhamnosus probiotikų paderme, poveikis dantų ėduonies vystymuisi. Autoriai padarè išvadą, kad vaikai, geriantys pieną, papildytą šiuo probiotiku, ypač 3-4 metų, turèjo gerokai mažiau dantų èduonies pažeistų dantų ir mažesni s. mutans skaičių, nei kontrolinès grupès vaikai [5]. Šie daug žadantys tyrimų rezultatai rodo, kad probiotikai yra potencialiai naudingi dantų ėduonies prevencijai.

Probiotikai ir periodontitas. Periodonto ligos skirstomos ị dvi grupes: tai gingivitas ir periodontitas. Gingivitas pasireiškia dantenų kraujavimu, paraudimu, paburkimu, o periodontitas pažeidžia ir gilesnius sluoksnius, įskaitant alveolès kaulą. Tai progresuojanti liga, dèl kurios prarandami dantys. Su periodontitu siejami sukèlejjai yra p. gingivalis, treponema denticola, tannerella forsythia ir aggregatibacter actinomycetemcomitans. Šioms bakterijoms būdingos ịvairios virulentiškos savybès, leidžiančios kolonizuotis giluminèse vietose ir sukeliančios audinių pažeidimą [5].

Probiotikai sukuria sveiką biofilmą ir apsaugo audinius nuo priedančio patogeninių bakterijų poveikio. Literatūros tyrimai rodo, kad tam tikrų mikroorganizmų buvimas priedančio audiniuose yra susijęs su padidèjusiu uždegiminių citokinų kiekiu, o lètiniu periodontitu sergančių individų peroralinis gydymas probiotikais sukelia reikšmingą priešuždegiminio atsako ị citokiną sumažejjimą ir klinikinių parametrų gerèjimą [14]. W. Teugel ir kiti tyrè šunis ir pastebejjo, kad gerujų bakterijų skyrimas kartu su konkrementų šalinimo procedūra gali slopinti patogenų rekolonizaciją periodonto kišenėse ir mažinti kraujavimo lygị [15]. Tas pats poveikis pastebètas ir žmonèms. Dvi savaites kramtomosios gumos su probiotikais vartojimas sumažino pacientų dantenų uždegimą [13]. P. Krasse ir kt. atliko tyrimą, kurio metu pacientų, gydytų probiotiku su 1. reuteri grupeje, pastebètas gingivito indekso ir bakterinio apnašo kiekio sumažejjimas, lyginant su placebo grupe. Tyrèjai padarè išvadą, kad šis probiotikas veiksmingas, siekiant sumažinti gingivito ir bakterinių apnašų susidarymą pacientams, sergantiems vidutinio sunkumo ir sunkiu gingivitu [16]. Pasak P. Koll-Klais ir kt., didelis laktobacillus kiekis mikrobiotoje slopino porphyromonas gingivalis ir prevotella intermedia bakterijų augimą (82\% ir 65\%) [17], tačiau yra studijų, kurių rezultatai neįrode probiotikų teikiamos naudos [18].

Probiotikai ir halitozė. Halitozė yra nemalonus burnos kvapas, sukeliantis diskomfortinę būseną, nuo kurios kenčia ivvairaus amžiaus žmonès, sudarantys apie 30 proc. populiacijos [19]. Halitozès priežasčių yra daug (tam tikrų maisto produktų vartojimas, metaboliniai sutrikimai, kvèpavimo takų infekcija), tačiau daugeliu atvejų pagrindinès priežastys - periodontitas ir dantų èduonis $[14,5]$. Halitozę sukelia anaerobinès sierą gaminančios bakterijos. Šios bakterijos kaupiasi liežuvio paviršiuje ir gerklèje, kur natūraliai dauginasi. Jos padeda virškinti maistą, suskaidydamos baltymus. Maiste esantys baltymai užsilieka burnos gleivineje, ypač parodontozès ar kituose pažeistuose burnos audiniuose. Tam tikromis sąlygomis šios bakterijos ima labai greitai skaidyti baltymus, kurie sudaryti iš amino rūgščių. Dviejų amino rūgščiu (cisteino ir metoinino) sudettyje gausu sieros. Kai bakterijos skaido baltymus ị amino rūgštis, gaminama siera, sukelianti halitozę.

M.Kang ir jo kolegos pranešè, kad ịvairios w. cibaria padermès slopina lakiųjų sieros junginių gamybą. Jie priejo prie išvados, kad šis teigiamas poveikis atsiranda dél vandenilio peroksido gaminimo w. cibaria. Autoriai taip pat nustatė, kad skalavimas skysčiu, turinčiu probiotiko w. cibaria, buvo susijęs su sieros junginių sumažèjimu ir blogo kvapo susilpnèjimu [5]. Kramtomosios gumos ar čiulpiamuju tablečių su probiotiku s.salivarius K12 vartojimas taip pat mažino lakiưjų sieros junginių kiekị pacientams, kuriems diagnozuota halitozè $[20,21]$.

\section{Išvados}

Atlikus mokslinių šaltinių analizę galima teigti, kad dar nepakanka probiotikų veiksmingumą patvirtinančiu įrodymų. Nepakanka aiškių įrodymų, siekiant sumažinti dantų eduonį, tačiau gingivito ir periodontito gydymui probiotikų terapija teikia daug žadančių rezultatų [10]. 


\section{Literatūra}

1. Mahasneh SA, Mahasneh AM. Probiotics: a promising role in dental health. Dental J (Basel) 2017; 5(4);26.

https://doi.org/10.3390/dj5040026

2. Stamatova I, Meurman JH. Probiotics: health benefits in the mouth. Am J Dent 2009;22(6):329-38.

3. Bizzini B, Pizzo G, Scapagnini G, Nuzzo D, Vasto S. Probiotics and oral health. Curr Pharm Des 2012; 18(34):5522-5531. https://doi.org/10.2174/138161212803307473

4. Bulotienè I, Jagelavičienè E. Probiotikų svarba burnos ligų profilaktikai ir gydymui. Vilnius, Sveikatos mokslai, 2018;3(28):71-74.

5. Bonifait L, Chandad F, Grenier D. Probiotic for oral health: myth or reality? J Can Dent Assoc 2009;75(9).

6. Meurman JH, Stamatova IV. Probiotics: evidence of oral health implications. Folia Med (Plovdiv) 2018;60(1):21-29.

https://doi.org/10.1515/folmed-2017-0080

7. Alok A, Singh ID, Singh S, Kishore M, Jha ChP, Iqubal A. Probiotics: a new era of biotherapy. Adv Biomed Res 2017; 6:31. https://doi.org/10.4103/2277-9175.192625

8. Pradeep K, Kuttappa MA, Prasana KR. Probiotic and oral health: an update. SADJ 2014;69(1):20-4.

9. Gungor OE, Kirzioglu Z, Kivanc M. Probiotics: can they be used to improve health? Benef Microbes 2015;6(5):647-56. https://doi.org/10.3920/BM2014.0167

10. Gruner D, Paris S, Schwendicke F. Probiotics for managing caries and periodontitis: systematic review and meta-analysis. Dent 2016;48:16-25. https://doi.org/10.1016/j.jdent.2016.03.002

11. Kolenbrander PE, Palmer RJ, Jr, Rickard AH, Jakubovics NS, Chalmers NI, Diaz PI. Bacterial interactions and successions during plaque development. Periodontol 2006; 42:47-79. https://doi.org/10.1111/j.1600-0757.2006.00187.x

12. Fernandez AJF, Domingo TA, Oltra DP, Diago MP. Probiotic treatment in the oral cavity: an update. Med Oral Patol Oral Cir Bucal 2010;15(5):e677-80. https://doi.org/10.4317/medoral.15.e677

13. Twetman S, Derawi B, Keller M, Ekstrand K, Yucel-Lindberg T, Stecksen-Blicks C. Short-term effect of chewing gums containing probiotic lactobacillus reuteri on the levels of inflammatory mediators in gingival crevicular fluid. Acta Odontol Scand 2008:1-6. https://doi.org/10.1080/00016350802516170

14. Haukioja A. Probiotics and oral health. Eur J Dent 2010; 4(3):348-355

https://doi.org/10.1055/s-0039-1697851

15. Teugel W, Newman MG, Coucke W, Haffajee AD, Van Der Mei HC, Haake SK, et al. Guiding periodontal pocket recolonization: a proof of concept. J Dent Res 2007; 86:1078-82. https://doi.org/10.1177/154405910708601111

16. Krasse P, Carlsson B, Dahl C, Paulsson A, Nilsson A, Sinkiewicz $\mathrm{G}$. Decreased gum bleeding and reduced gingivitis by the probiotic lactobacillus reuteri. Swed Dent J 2006;30(2):55-60.

17. Koll-Klais P, Mandar R, Leibur E, Marcotte H, Hammarstrom
L, Mikelsaar M. Oral lactobacilli in chronic periodontitis and periodontal health: species composition and antimicrobial activity. Oral Microbiol Immunol 2005; 20(6):354-61.

https://doi.org/10.1111/j.1399-302X.2005.00239.x

18. Teughels W, Durukan A, Ozcelik O, Pauwels M, Quirynen M, Haytac MC. Clinical and microbiological effects of lactobacillus reuteri probiotics in the treatment of chronic periodontitis: a randomized placebo-controlled study. J Clin Periodontol 2013;40(11):1025-35. doi: 10.1111/jcpe.12155.

https://doi.org/10.1111/jcpe.12155

19. Keller MK, Bardow A, Jensdottir Th, Lykkeaa J, Twetman S. Effect of chewing gums containing the probiotic bacterium lactobacillus reuteri on oral malodour. Acta Odontol Scand 2012;70(3): 24650.

https://doi.org/10.3109/00016357.2011.640281

20. Burton JP, Chilcott CN, Moore CJ, Speicer G, Tagg JR. A preliminary study of the effect of probiotic Streptococcus salivarius K12 on oral malodour parameters. J Appl Microbiol 2006;100(4):754-64.

https://doi.org/10.1111/j.1365-2672.2006.02837.x

21. Burton JP, Chilcott CN, Tagg JR. The rationale and potential for reduction of oral malodour using Streptococcus salivarius probiotics. Oral Dis 2005;11(1):29-31.

https://doi.org/10.1111/j.1601-0825.2005.01084.x

\section{PROBIOTICS AND ORAL HEALTH E. Daugẻlienė, J. Andruškienė}

Keywords: probiotics, oral health, dental caries, periodontitis, halitosis.

Summary

The benefits of probiotics to the human body have long been known, but the last twenty years of research and use of probiotics have become very popular [1]. According to the World Health Organization, probiotics - living microorganisms (bacteria, yeasts, etc.) that are used in suitable amounts are beneficial for human health. Due to its positive properties, probiotics are added to a variety of foods. The term for probiotics was first mentioned in 1965. Probiotics are the microflora naturally present in the gastrointestinal tract and the urogenital system in the mucous membrane [2]. Current research has shown that the balance between beneficial and pathogenic bacteria is necessary to maintain oral health [3]. The most commonly occurring probiotics are Lactobacillus and Bifidobacterium. Probiotics can help restore the balance of the microflora of the mouth. In the probiotic study, it has been observed that certain probiotic strains can be useful for oral cavity and help to combat the most common oral disorders - dental caries, bad breath (halitosis) and periodontitis [4].

Correspondence to: evelinadaugeliene@gmail.com

Gauta 2019-12-06 